\title{
8
}
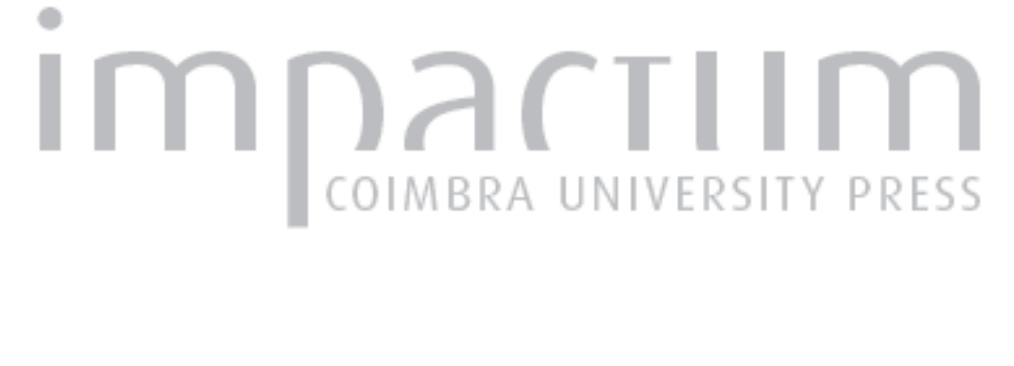

\section{O fundo António de Lima Fragoso na Biblioteca Geral da Universidade de Coimbra}

Autor(es): $\quad$ Ramires, Isabel João; Nogueira, Sandra

Publicado por: Imprensa da Universidade de Coimbra

URL persistente:

URl:http://hdl.handle.net/10316.2/42754

DOI:

DOI:https://doi.org/10.14195/1647-8436_46_47_7

Accessed : $\quad$ 26-Apr-2023 13:34:37

A navegação consulta e descarregamento dos títulos inseridos nas Bibliotecas Digitais UC Digitalis, UC Pombalina e UC Impactum, pressupõem a aceitação plena e sem reservas dos Termos e Condições de Uso destas Bibliotecas Digitais, disponíveis em https://digitalis.uc.pt/pt-pt/termos.

Conforme exposto nos referidos Termos e Condições de Uso, o descarregamento de títulos de acesso restrito requer uma licença válida de autorização devendo o utilizador aceder ao(s) documento(s) a partir de um endereço de IP da instituição detentora da supramencionada licença.

Ao utilizador é apenas permitido o descarregamento para uso pessoal, pelo que o emprego do(s) título(s) descarregado(s) para outro fim, designadamente comercial, carece de autorização do respetivo autor ou editor da obra.

Na medida em que todas as obras da UC Digitalis se encontram protegidas pelo Código do Direito de Autor e Direitos Conexos e demais legislação aplicável, toda a cópia, parcial ou total, deste documento, nos casos em que é legalmente admitida, deverá conter ou fazer-se acompanhar por este aviso.

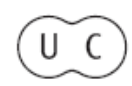




\section{BOLETIM DA \\ BIBLIOTECA GERAL DA UNIVERSIDADE DE COIMBRA}

VOL. 46/47 (2015/2016)

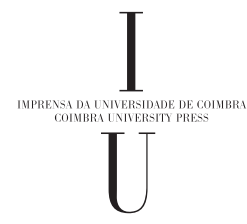




\section{O fundo António de Lima Fragoso na Biblioteca Geral da Universidade de Coimbra}

Isabel João Ramires ${ }^{1}$

Sandra Nogueira ${ }^{2}$

\section{RESUMO}

António de Lima Fragoso, pianista e compositor, morreu aos 21 anos deixando uma expressiva obra musical que, apesar de naturalmente incompleta, é considerada cultural e historicamente relevante e de elevado valor artístico musical. Com o apontamento de alguns dados crono-biográficos de António Fragoso, apresenta-se uma descrição do Fundo doado à BGUC em 2014 pela família, que compreende o espólio musical e literário do compositor, incluindo correspondência, já devidamente organizado e incorporado no acervo musical e musicológico da BGUC.

\section{PALAVRAS-CHAVE}

António de Lima Fragoso (1897-1918). Músico português, arquivo privado, espólio musical.

\section{ABSTRACT}

António de Lima Fragoso, Portuguese pianist and composer, died at the age of 21 leaving an expressive musical work of high musical value which,

1 Bibliotecária da Biblioteca Geral da Universidade de Coimbra - iramires@bg.uc.pt

2 Documentalista e arquivista do Centro de Documentação e Informação da Cena Lusófona (Coimbra), entre 2009 e 2015. Colaboradora da Biblioteca Geral da Universidade de Coimbra no tratamento do Fundo António de Lima Fragoso.smbar@ hotmail.com 
although unfinished, is considered an important moment in the history of Portuguese music. With biographical data referring to António Fragoso, this article provides a description of the family archive donated to BGUC by his family in 2014, in particular of the composer's personal papers, including his musical works and correspondence, properly organised and incorporated into the BGUC's manuscript and musical Fund.

\section{KEYWODS}

António de Lima Fragoso (1897-1918). Portuguese musician, private archive, musical archive.

A 21 de maio de 2014, na Biblioteca Joanina, foi assinado o protocolo de doação do espólio musical e literário de António de Lima Fragoso à Biblioteca Geral da Universidade de Coimbra (BGUC), pela Associação António Fragoso e a Família Fragoso Martins Soares, numa cerimónia presidida pelo Reitor da Universidade, Professor Doutor João Gabriel Silva, com a presença do Diretor da Biblioteca Geral, Professor Doutor José Augusto Cardoso Bernardes e da Vice-Reitora Professora Doutora Clara Almeida Santos.

O Fundo António de Lima Fragoso, em que sobressai o conjunto dos manuscritos musicais e as primeiras edições das obras do jovem compositor, morto precocemente aos 21 anos, em 1918, assume particular importância para a história da música portuguesa e a história do ensino da música em Portugal no Século XX. Este Fundo constitui um testemunho vívido das dinâmicas educativas, artístico-cultural e social, numa época convulsiva que se revelou fulcral para o País e o Mundo - os anos das mudanças decorrentes da implantação do regime republicano em Portugal, no contexto da Grande Guerra. O génio musical, a originalidade e a tragédia pessoais, pelos quais António Fragoso adquiriu um lugar próprio no panorama musical português, tornam este arquivo verdadeiramente excecional. 
2.

António de Lima Fragoso, nasceu na Pocariça (Concelho de Cantanhede), em 17 de junho de 1897, sendo filho primogénito de Viriato de Sá Fragoso (1872-1945), bacharel em Direito pela Universidade de Coimbra, contador judicial da Comarca de Cantanhede, e Maria Isabel de Sá Lima Fragoso, ambos naturais daquela localidade. Cresceu numa família tradicional alargada, com fortes hábitos conviviais e de lazer. O teatro, a música e a leitura, faziam parte do seu quotidiano, sobretudo em épocas de férias, quando a família e os amigos se reuniam e organizavam bailes, saraus, récitas teatrais e pequenos concertos, abertos à comunidade local, em que cada um participava conforme os seus talentos. No amplo círculo da família Lima Fragoso, grande parte dos membros possuía formação académica superior ou artística, os homens, e formação artística algumas mulheres. Neste meio, António Fragoso foi, desde cedo, estimulado a desenvolver as suas capacidades literárias e musicais.

Na infância, iniciou a aprendizagem da música com António dos Santos Tovim, seu tio, médico em Cantanhede e melómano³.

Entre 1907 e 1910, no Porto, António Fragoso frequentou as aulas privadas de Piano do prestigiado professor, pianista, compositor e crítico musical, Ernesto Maia4. Em 1909 e 1910, participou nas audições públicas dos alunos daquele professor, no Salão do Cen-

3 António dos Santos Tovim, tio de António Fragoso pelo casamento com D. Henriqueta de Sá Lima, irmã de Maria Isabel de Sá Lima Fragoso, formado em Medicina pela Universidade de Coimbra, dedicava os tempos livres ao teatro e à música. A. Soares, atribui-Ihe a autoria do passe-calle «Boas vindas» que fazia parte do repertório da Estudantina (Tuna) Académica de Coimbra, em 1895 (cf. Soares (1958 ago. 1), p. 492).

4 Ernesto Maia foi, no final do século XIX, um dos precursores da reforma do ensino da música em Portugal que teve lugar em 1901. Defensor da criação de um Conservatório de Música na cidade do Porto, fez parte do grupo de fundadores desta escola, inaugurada no ano letivo de 1917-1918. 
tro Comercial do Porto, com interpretações de piano de obras de Mendelssohn e Godard 5 .

Não obstante as suas capacidades artístico-musicais e o seu interesse, cada vez maior, pelos assuntos de música, concluído o curso geral dos Liceus, António Fragoso matriculou-se, em outubro de 1912, no Curso Superior de Comércio do Instituto Industrial e Comercial do Porto.

As suas primeiras composições datam provavelmente desta época: embora não subsistam os originais manuscritos, deduz-se que a peça intitulada "Cantigas da nossa terra" foi interpretada pela primeira vez a 1 de janeiro de 1913, por senhoras da Pocariça, a quem o compositor a consagrou, conforme a dedicatória «Às Senhoras que primeiro a cantaram em 1 de Janeiro de 1913», na edição das Toadas da minha aldeia ${ }^{6}$.

Outra das suas criações foi uma valsa, para piano: Ingénua. Conforme testemunho documental' ${ }^{7}$, esta terá inclusivamente sido das primeiras obras que o compositor tentou publicar ${ }^{8}$.

5 Cf. ROSA (2010) p.119.

6 Cf. FRAGOSO, A. (1916). Toadas da minha aldeia, canções a uma e duas vozes (p. 4). Lisboa: Valentim de Carvalho.

7 Conserva-se no Fundo o desenho original de uma capa com o título Ingénua, valsa para piano, Porto, MXCXIII, a tinta-da-china e a tinta vermelha sobre cartolina, assinado e datado por Jorge da Cruz Jorge. Conforme António Fragoso, carta, 9 março 1913, a Jorge da Cruz Jorge, disponível no Fundo, a capa destinar-se-ia à impressão de uma partitura. A peça musical com este título, de que existem no Fundo dois manuscritos, um dos quais inacabado, mantém-se inédita.

8 Leonardo Jorge menciona que António Fragoso, na viagem a Lisboa, teria obtido do editor de música Valentim de Carvalho a promessa de publicação das suas peças, aludindo às Toadas, projeto que não se concretizou (cf. JORGE (1968) p. 27). Talvez uma das peças então propostas para publicação tenha sido esta valsa. 


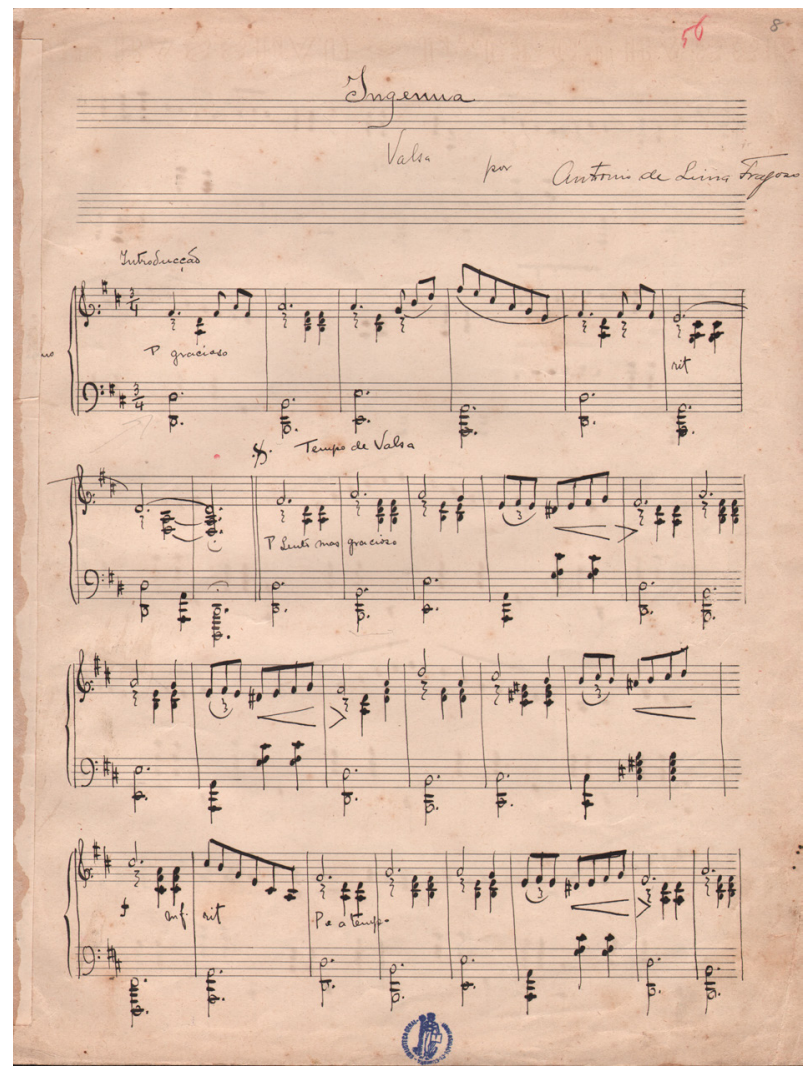

Fig. 1: Partitura de uma das primeiras composições de António de Fragoso, Ingenua, valsa (1913).

Entre os grandes impulsionadores e apoiantes da sua carreira artística, António Fragoso contou com Jorge da Cruz Jorge (18901966 ? ${ }^{9}$, amigo próximo, apesar da diferença de idades, a quem se deve o testemunho direto da criatividade precoce do compositor.

9 Jorge da Cruz Jorge (1890-1966?), licenciado em Direito pela Universidade de Coimbra, advogado em Cantanhede, colaborador do jornal Correio de Cantanhede, artista plástico e ator amador. Em 1918, ingressou na Escola de Oficiais Milicianos, mudando-se para Lisboa (Cf. FRAGOSO, V.S. (s. d.) pp. 176-177). Leonardo Jorge atribui a J. da Cruz Jorge a iniciativa da estreia absoluta da composição de António Fragoso «Cantigas da nossa terra», pelas senhoras da Pocariça (cf. JORGE (1968) pp. 26). 


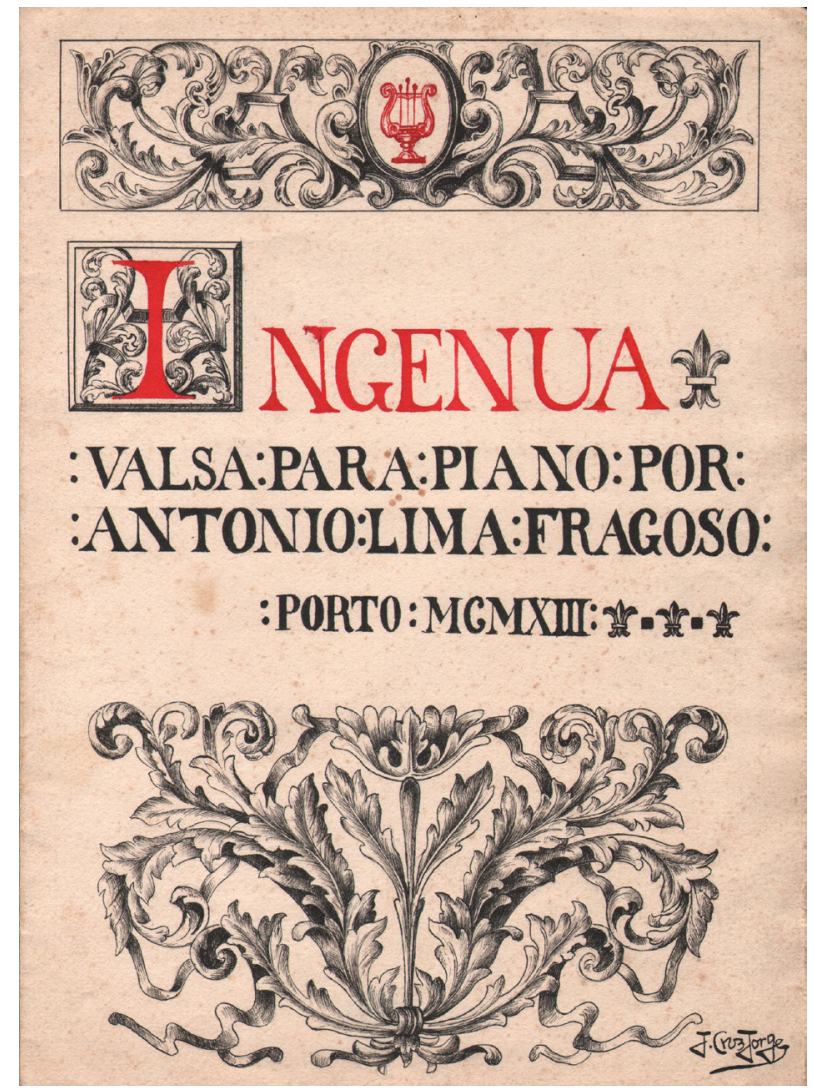

Fig. 2: Desenho da capa para a publicação da valsa Ingénua, que não chegou a ser editada.

Um rascunho a lápis da valsa Ingénua, inacabado, encontra-se nas folhas finais de um caderno que contém uma cópia, muito cuidada, de Composições para piano, permitindo supor terem sido produzidas na mesma época, 1913.

Datam destes anos do Porto os primeiros ensaios literários de António Fragoso que se conservam, por vezes ilustrados com esforçados desenhos à pena, a tinta-da-china e a carvão ${ }^{10}$.

10 Veja-se, por exemplo, António Fragoso, Narração dum passeio à beira dum rio, Pocariça, 2-10-1909, original autógrafo, ilustrado, dedicado pelo autor ao pai, «no dia do seu aniversário», disponível no Fundo. 
No segundo período do ano letivo de 1913-1914, em março, António Fragoso desistiu do curso comercial ${ }^{11}$, e, vendo reconhecida a sua vocação artístico-musical, concorreu - com o incentivo e o total apoio dos seus pais e outros familiares ${ }^{12}$ e sob a proteção do seu tio e padrinho, Professor Doutor José d'Oliveira Lima ${ }^{13}$ - a pensionista do Estado no estrangeiro, prestando provas pianísticas ${ }^{14}$.

Apesar do insucesso no concurso, António Fragoso instalou-se em Lisboa, preparando-se para ingressar na Escola de Música do Conservatório Nacional.

Durante a sua formação musical, residiu temporariamente em Caxias e depois em Lisboa, primeiro na Rua Rodrigo da Fonseca, e, seguidamente, na Avenida Duque de Ávila, em casa de seu tio materno e encarregado de educação, Pedro de Sá Lima.

Embora rodeado pelos tios e pelos primos, o estudante não descurou o estreito relacionamento com os pais e os irmãos e, durante a sua permanência em Lisboa, procurou mantê-los a par de todas as suas atividades escolares, artísticas e lúdicas, das suas expetativas e

11 Cf. FRAGOSO, V. S. (1997) pp. 179.

12 Sobre o apoio familiar à carreira musical de António Fragoso e a reação do adolescente aos estímulos para prosseguir a sua vocação, veja-se António Fragoso, carta, 28-8-913, ao pai, e carta, maio 2014, ao pai e ao padrinho, originais disponíveis no Fundo.

13 José de Oliveira Lima (1875-1950), professor catedrático da Faculdade de Medicina da Universidade do Porto, de que foi Vice-Reitor, médico higienista e pedagogo, fundou e dirigiu naquela cidade um inovador e modelar estabelecimento de ensino para alunos em regime de internato e externato - o Instituto Moderno do Porto (1914-1918). Participaram na criação deste colégio, na sua direção e na docência, Viriato de Sá Fragoso e o seu irmão, o padre Carlos de Sá Fragoso (1876-1948), Bispo de Meliapor (Índia) e professor de Filosofia. José de Oliveira Lima, que se distinguiu pelo cultivo das artes (teatro, pintura, fotografia e música), desempenhou um papel fundamental na formação e orientação vocacional de António Fragoso.

14 Tratava-se do concurso de admissão ao pensionato em países estrangeiros para o estudo de arte musical, cujos prazo de abertura e conteúdo das provas foram publicados no "Programa do concurso para pensionista do Estado no estrangeiro na classe de contraponto, fuga e composição", Diário do Governo, n. ${ }^{\circ} 250$, de 20 de outubro de 1913. Sobre a prestação de António Fragoso, veja-se ROSA (2010) p.123. 
dos seus projetos, das suas relações académicas, das suas dificuldades e dos seus êxitos, através de correspondência assídua ${ }^{15}$. O envio regular de notícias era também uma exigência paterna.

No final de 1913, António Fragoso encontrava-se inscrito no Instituto Luso-Germânico, um colégio feminino de Lisboa ${ }^{16}$. Segundo a explicação que ele próprio deu, foi o Professor Tomás Borba ${ }^{17}$ que o matriculou naquele colégio como seu aluno ${ }^{18}$.

Entretanto, passou a receber lições privadas de piano, do professor pianista Marcos Garin ${ }^{19}$ e de Rudimentos, de Mariana Angélica Tremoulet da Silva Castro ${ }^{20}$.

Em maio de 1914, apresentou as suas composições - «Canções» (das Toadas da minha aldeia), Mazurcas, Coro dos peregrinos e dois Prelúdios (Prelúdios românticos) - a Marcos Garin, que as mostrou a Tomás Borba. As apreciações dos Professores entusiasmaram-no, considerando-as um grande elogio e um incentivo à criação de música para que se sentia vocacionado.

15 O conjunto dos originais de cartas e outros manuscritos de António Fragoso que se conservam no Fundo António de Lima Fragoso constitui uma das principais fontes para o conhecimento da personalidade e do percurso artístico do pianista compositor, para além de se terem revelado fundamentais para os processos de reconhecimento da sua escrita e de organização do seu espólio. A generalidade destas fontes está já estudada e exposta por Margarida Prates. Veja-se especialmente o capítulo «Contributos do acervo epistolar na redação de uma nova biografia» (PRATES (2014) p. 12-16).

16 Cf. ROSA (2014) p.119.

17 Tomás Borba (1867-1950), padre e compositor, professor de Harmonia e de História da Música do Conservatório Nacional de Lisboa.

18 Cf. António Fragoso, carta, [maio de 1914], [Lisboa], ao pai e ao padrinho, em que menciona, a propósito das inscrições para os exames do Conservatório, que o "Senhor Borba" o matriculou no Colégio Luso-Germânico como seu aluno.

19 Marcos Garin (1875-1955), professor da Escola de Música do Conservatório Nacional de Lisboa e da Academia de Amadores de Música. 


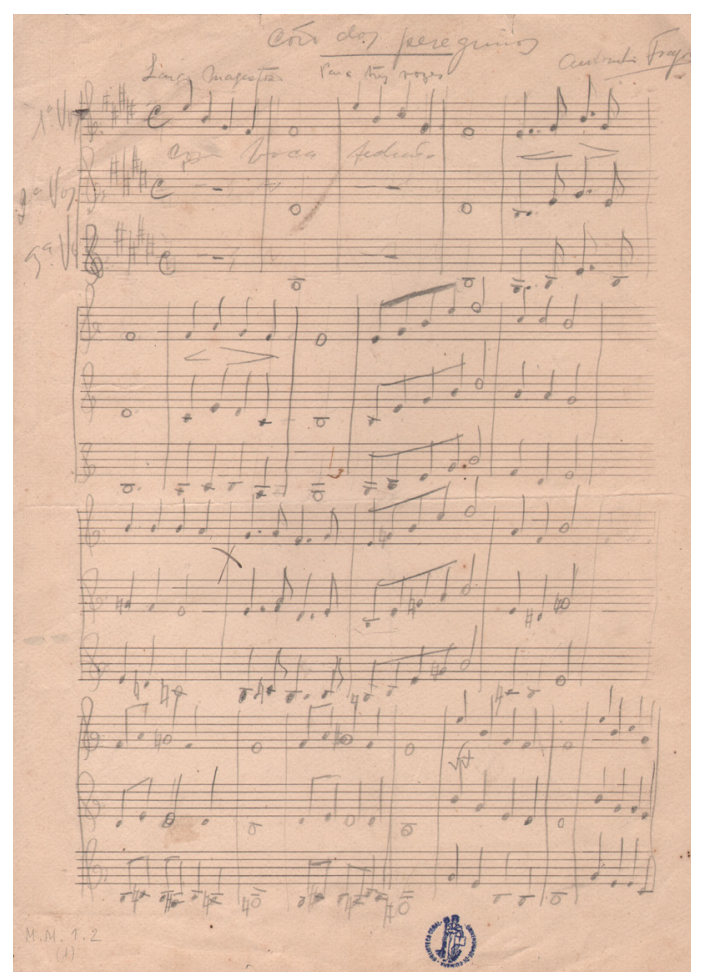

Fig. 3: Manuscrito da partitura da peça Coro dos Peregrinos, para três vozes, «com boca fechada» (1914?).

No final do mesmo mês, numa audição de alunos de Marcos Garin, interpretou ao piano um Prelúdio de Rachmaninov e Masques de Debussy tendo merecido algum destaque ${ }^{21}$.

Em julho de 1914, apresentou-se como aluno externo aos exames dos dois primeiros anos de Rudimentos e dos três primeiros anos do curso geral de Piano, que concluiu com êxito.

No ano letivo de 1914-1915, inscreveu-se como aluno interno do Conservatório no $1^{\circ}$ ano de Harmonia e no $4^{\circ}$ ano de Piano. Em fevereiro de 2015, no exame do $4 .^{\circ}$ ano de Piano, ficou classificado entre os alunos com extraordinárias aptidões artísticas e o aprovei-

$21 \mathrm{Cf}$. «A Festa dos alunos do Professor de piano sr. Marcos Garin no "Salão da Ilustração Portugueza"», Ilustração Portuguesa, 2. ' Série, 433 (8 jun. 1914) 734 e também ROSA (2014) p.119. 
tamento de «Muito Bom $»^{22}$. Neste mesmo ano concluiu os $4^{\circ}$ e $5^{\circ}$ anos do curso geral de Piano.

A partir de então, participou mais frequentemente em apresentações e audições públicas, essencialmente de âmbito formativo, obtendo os aplausos e os elogios do público, dos professores e dos críticos, na imprensa generalista e especializada ${ }^{23}$.

As obras 7 Prelúdios, Petite suite - que terá apresentado a Ruy Coelho (1889-1986) a propósito de uma eventual orquestração -, e Sonata, para piano, e Consolation, para canto e piano, são exemplos da intensa produção musical discente de António Fragoso, nos anos de 1914-1915.

Em todo o percurso escolar, António Fragoso distinguiu-se não só pelo talento como pianista-compositor, como pelo seu caráter, entusiasmo, criatividade e originalidade artísticas e dedicação à música, como testemunham os condiscípulos, Francine Benoît (1894-1990), António Fernando Cabral (1900-1976), Fernando de Sousa Botelho Leitão e Lourenço Varela Cid Júnior (1898-1987), os mestres, Marcos Garin, Tomás Borba, Luís de Freitas Branco (1890-1955), Rui Coelho, Alexandre Rey Colaço (1854-1928), entre outros, e os críticos encarregues da cobertura das atividades musicais na imprensa, como, por exemplo, Adriano Merêa (1865-1933), Alfredo Pinto (Sacavém) (1874-1945) e Oliva Guerra (1898-1982).

Em março de 1916, António Fragoso acompanhou ao piano duas condiscípulas que interpretaram Lieder de R. Schumann (1810-1856) num concerto no Conservatório de Lisboa ${ }^{24}$ e a 16 de maio de 1916, incentivado por alguns dos seus mestres e pelos condiscípulos e amigos, realizou a primeira audição pública exclusivamente preen-

22 Cf. ROSA (2014) p. 123.

23 Sobre as peças interpretadas no concerto na Academia de Amadores de Música, a 30 de março de 1915 e a receção pública das atuações, vd. no Fundo, os Programas respetivos e, entre muitos outros, os recortes dos jornais O Século (1 abr. 1915), e de A Arte Musical, 17:392 (15 abr. 1915) p. 61. 
chida com as suas próprias obras ${ }^{25}$, na Academia dos Amadores de Música, com uma excelente receção ${ }^{26}$. Ainda em maio, em nova edição de alunos no Conservatório, acompanhou ao piano uma aluna que também interpretou a canção Consolation. No mês seguinte, voltou a participar no concerto de alunos de Marcos Garin no Salão da Ilustração Portuguesa, com uma interpretação de Bach-Saint-Saëns ${ }^{27}$. No final do Verão, apresentou-se em concerto, no Casino da Curia, e estreou uma parte do seu Trio para violino, violoncelo e piano ${ }^{28}$.

Datam deste ano as suas composições Canção e dança portuguesas, para piano, e Suite para violino e piano ou Suite romantique ${ }^{29}$.

Datará igualmente de 1916, a edição pela Casa Valentim de CarvaIho das Toadas da minha aldeia, melodias para piano e voz, a primeira das duas obras que António Fragoso publicou em vida ${ }^{30}$.

25 Cf. António Fragoso, carta ao pai, [sem data, 22 de março de 1916], disponível no Fundo.

26 Vd. D. Modesto (Adriano Merêa). Academia dos Amadores de Música: audição de composições de António Fragoso. O Dia (17 maio 1916), disponível no Fundo em transcrição manuscrita. Informação da publicação na transcrição.

27 Cf. ROSA (2014) p.123-124.

28 Cf. JORGE (1968) p. 38.

29 Não se conserva no Fundo uma partitura manuscrita com o título Suite romantique, mas sim um manuscrito da parte de violino de uma Suite para violino e piano. Com base nos Programas de concertos promovidos na época pelo compositor em que consta a Suite romantique, para violino e piano, e em cartas de António Fragoso a familiares, existentes no Espólio, presume-se que se trata da mesma obra. A peça foi também publicada com o título Suite romantique, com revisão de Álvaro Cassuto, em FRAGOSO, A. (1971). António Fragoso: obras póstumas (vol. 3 pp. 3-25). Lisboa: [Valentim de Carvalho].

30 Data da edição atribuída com base na dedicatória autógrafa do compositor a seus pais e a seus irmãos, firmada a 16 de maio de 1916 na capa do exemplar conservado no Fundo. 


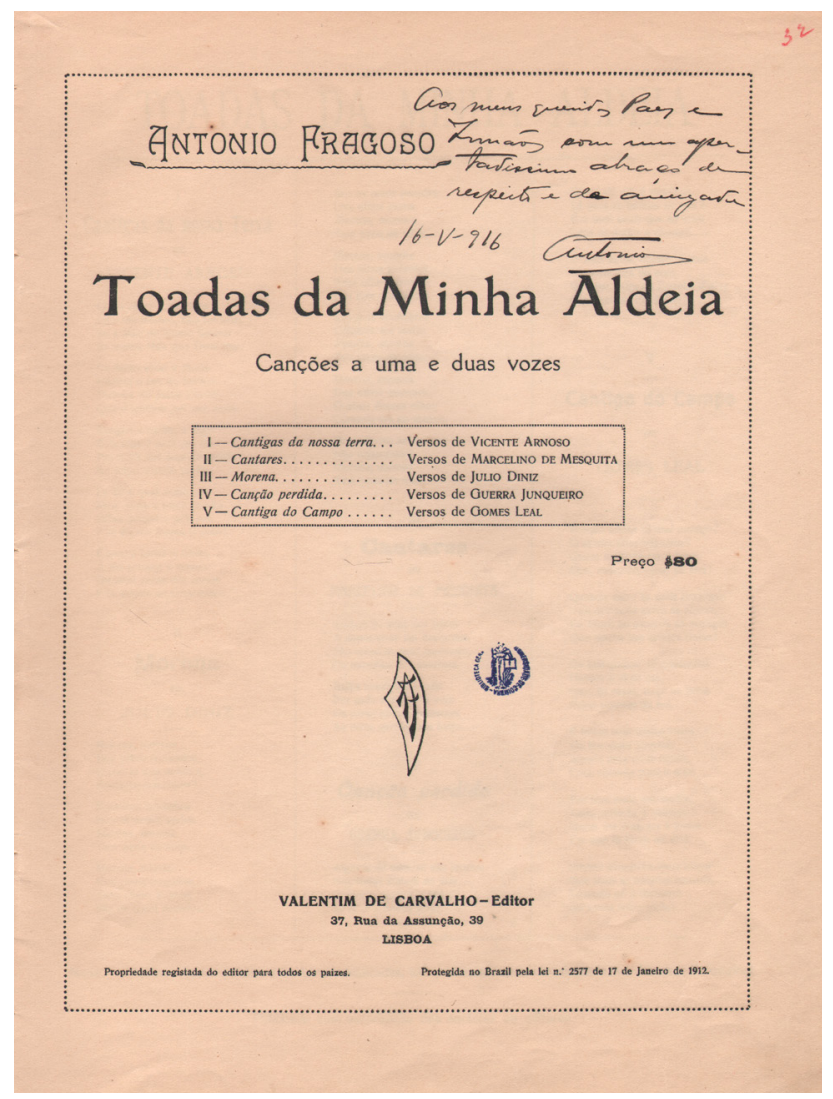

Fig. 4: Dedicatória autógrafa de António Fragoso, datada de 1916, na página de rosto da partitur a Toadas da minha aldeia: canções a uma e duas vozes.

Durante o ano letivo de 1916-1917, António Fragoso ter-se-á exercitado mais arduamente como intérprete pianístico, tendo obtido no final do ano excelentes notas nos exames de Piano e Acompanhamento para além de um prémio de interpretação $0^{31}$. As classificações obtidas contrastam porém com os resultados a Harmonia, como já havia acontecido no ano anterior ${ }^{32}$. Como compositor, durante este

31 Cf. ROSA (2014) p. 124; o autor referencia também, no início do ano letivo de 191718, a atividade de António Fragoso como monitor do 1. ano de piano na classe de Marcos Garin e o prémio pecuniário que o pianista recebeu «pela sua participação em agrupamentos de música de câmara».

32 Cf. António Fragoso, carta de 23 jul. 1917, [Lisboa?] ao pai, disponível no Fundo. 
período escreveu Lieder, para voz feminina, sobre poemas do poeta francês Paul Verlaine (1844-1896), e composições para pequenos conjuntos de instrumentos. Em março de 1917, António Fragoso preparava uma composição para orquestra de cordas, com harpas ${ }^{33}$ e, provavelmente, a peça Pensées extatiques, para piano, que ficou inacabada.

Por esta altura, o jovem compositor passou a firmar os seus trabalhos e as suas cartas com uma nova assinatura, o que é relevante para a datação e identificação dos seus manuscritos ${ }^{34}$.

A 18 de abril de 1917, António Fragoso apresentou no concerto realizado por ocasião da comemoração do $10 .^{\circ}$ aniversário da fundação da Academia de Ciências de Portugal ${ }^{35}$, o seu Trio para violino, violoncelo e piano. Autocrítico, em carta, de 25 de abril, confessou ao pai não estar satisfeito com a atuação, que não correu bem, não obstante os elogios recebidos ${ }^{36}$. No mesmo concerto interpretou duas peças para piano, de Luís de Freitas Branco, que lhe agradeceu a atuação e a boa vontade demonstradas e o elogiou pelo manifesto talento ${ }^{37}$.

33 Cf. António Fragoso, carta de março 1917, Lisboa, ao irmão Carlos, também disponível no Fundo.

34 António Fragoso comunica a alteração de assinatura em carta, sem data, que dirige a seu pai, provavelmente enviada entre 2 e 12 de junho de 1917. No final de uma partitura musical, datada de maio de 1917, de que se conserva apenas a folha final, contendo os últimos compassos, podem ver-se vários exercícios de assinatura para a fixação da nova grafia.

35 Academia científica e literária fundada em 1907-1908 por um grupo republicano encabeçado por Teófilo Braga (1843-1924) e Tomás Cabreira (1865-1918), com o propósito do fomentar e divulgar os estudos científicos, históricos e literários, em concurso com a Academia Real das Ciências de Lisboa. Nos primeiros anos da República, após a aprovação dos seus estatutos, a Academia de Ciências de Portugal funcionou como órgão consultivo do Governo. A instituição extinguiuse em 1925-1926.

36 Sobre a participação de António Fragoso na Sessão, veja-se o certificado da Academia de Ciências de Portugal, datado 8 jul. 1917, em transcrição manuscrita, com lapso no nome da Academia, e também carta anteriormente mencionada, disponíveis no Fundo.

37 Cf. Luís de Freitas Branco, carta, de 19 de abril de 1917, a António Fragoso, disponível no Fundo. 

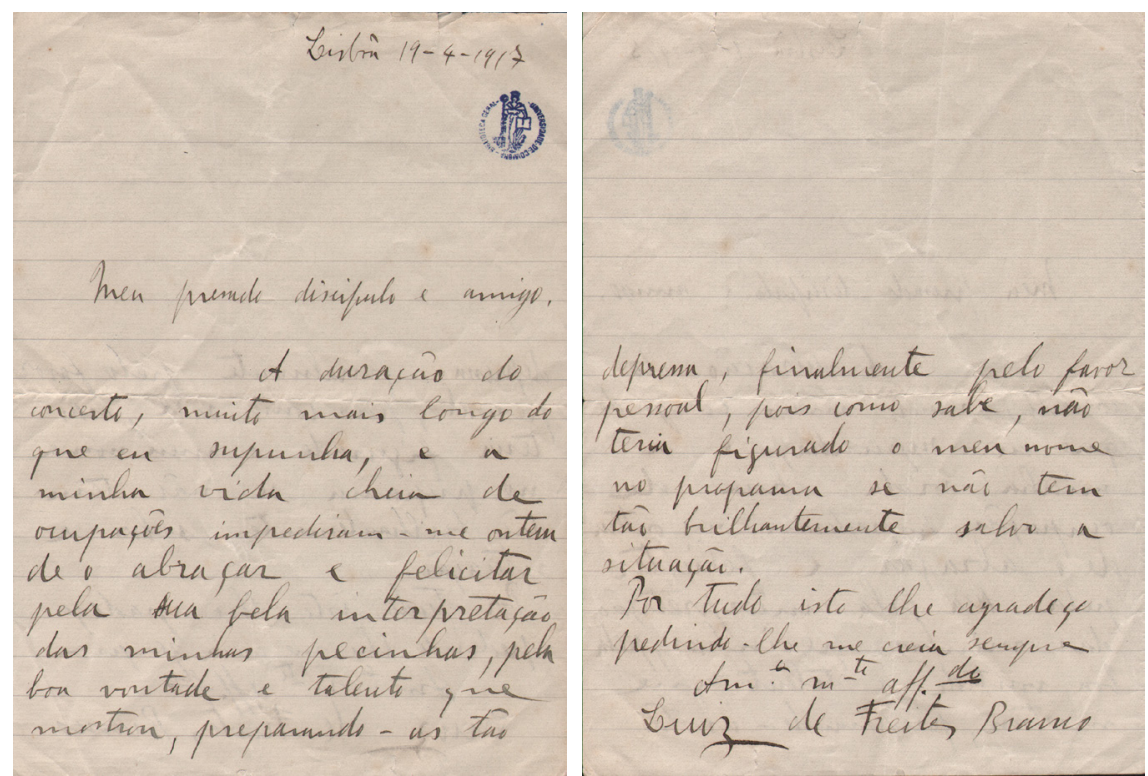

Fig. 5: Carta de Luís de Freitas Branco ao «discípulo e amigo» António Fragoso, Lisboa, 19-4-1917.

A 20 de maio de 1917, na audição de alunos de Marcos Garin, duas condiscípulas de António Fragoso interpretaram os andamentos «Ária» e "Gavotte» das suas Três peças do Seculo XVIII para piano, e, a 27 de maio, Vasco Garin interpretou o «Minuete», tendo assim estreado a segunda e última das suas obra que ele próprio publicou $^{38}$.

38 FRAGOSO, A (1917). Três peças do século XVIII: para piano. Lisboa, Valentim de Carvalho. Dois dos três exemplares da partitura existentes no Fundo ostentam dedicatórias autógrafas, datadas de abril de 1917. 


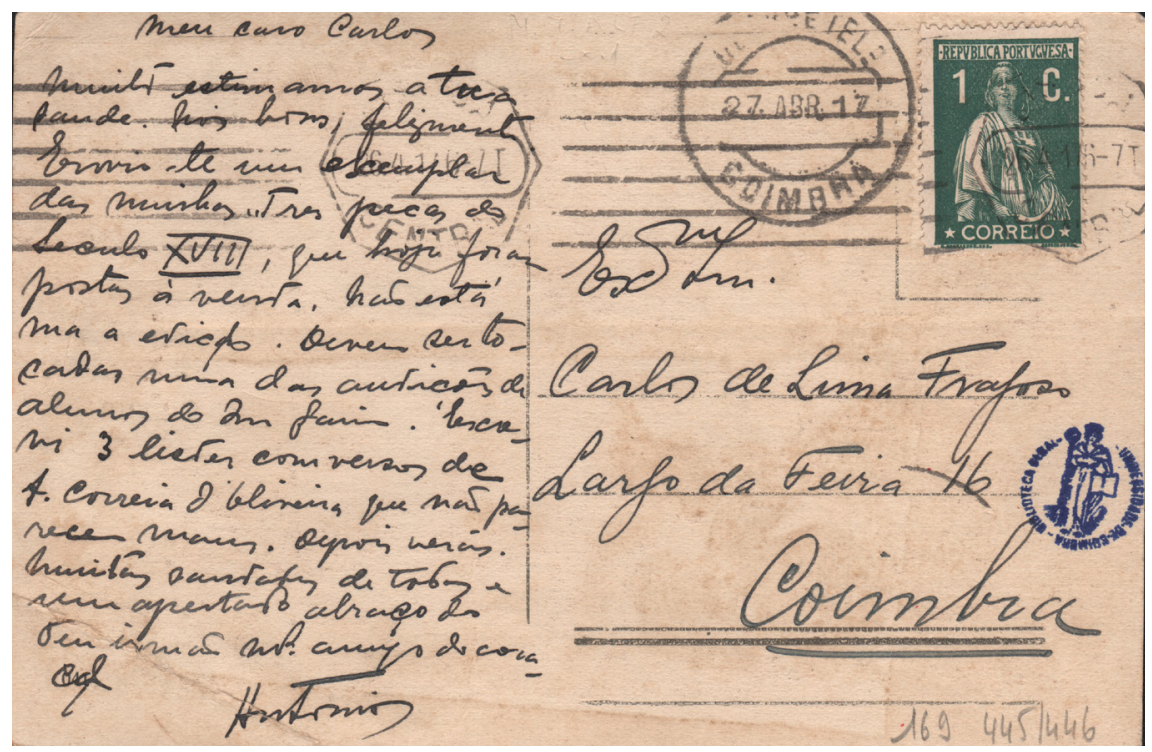

Fig. 6: António Fragoso em bilhete-postal, 27 abr. 1917, Lisboa, anuncia ao irmão a edição das Três peças do Século XVIII.

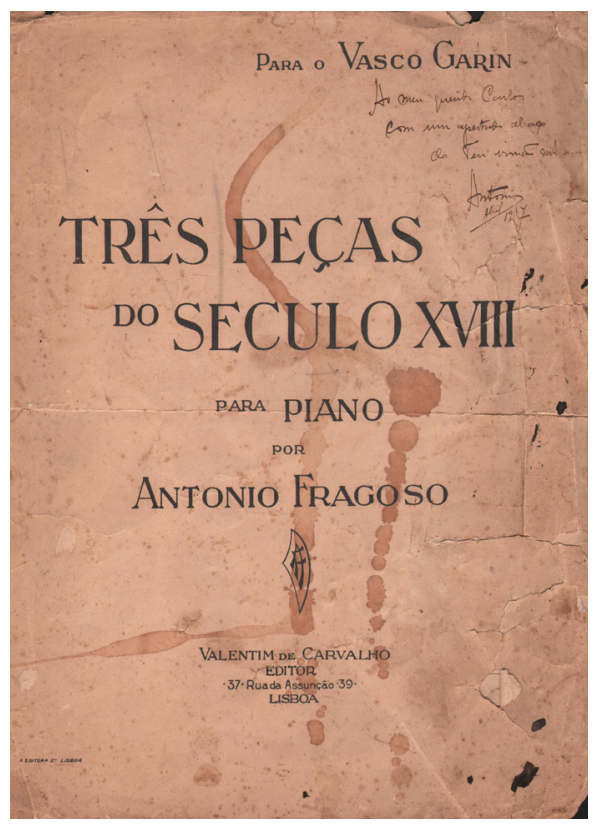

Fig. 7: Capa do exemplar da partitura oferecido por António Fragoso ao irmão, com dedicatória autógrafa datada de 1917. 
A 2 de junho de 1917, António Fragoso promoveu um Sarau Musical na Academia de Amadores de Música, em honra de António Fernando Cabral que, na ocasião, foi presenteado com um violino. Novamente foram interpretadas peças de António Fragoso ${ }^{39}$, que também proferiu o discurso de homenagem ao violinista. Ainda em 1917, escreveu as peças Poèmes saturniens, sobre versos de Paul Verlaine, para canto e piano, e o Nocturno em Re $b$ maior, dedicado ao mestre Luís de Freitas Branco, entre outras.

Nas férias de verão de 1917, António Fragoso e Fernando Cabral realizaram uma digressão por várias estâncias de férias, em termas e praias do Centro e Norte do país, apresentando-se em concertos cujos programas incluíam a interpretação de compositores contemporâneos, nacionais e estrangeiros, e as suas próprias composições ${ }^{40}$. O produto da venda dos bilhetes de ingresso para assistir aos concertos reverteria, pelo menos em parte, para os dois jovens músicos.

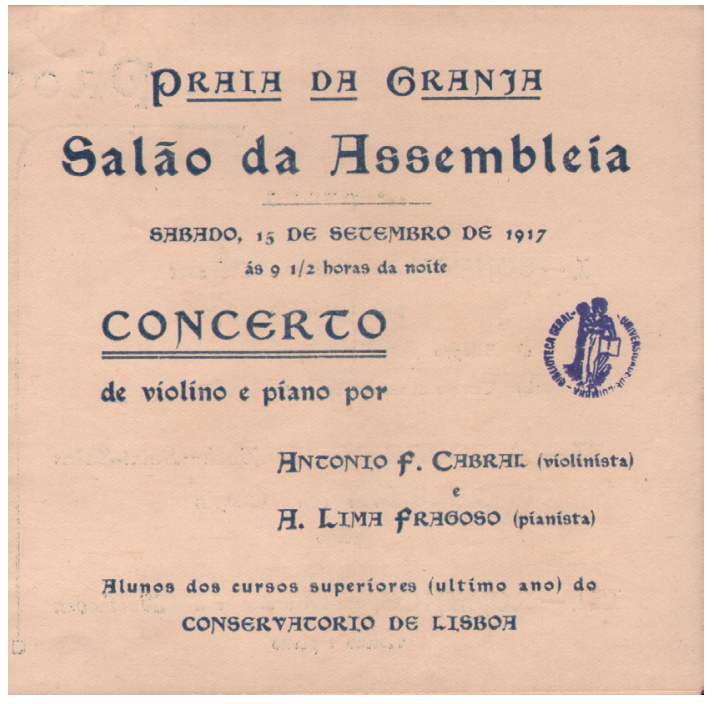

39 Veja-se o Convite [para o] Sarau Musical promovido por António Fragoso, sábado, 2 de junho de 1917 [no] Salão da Academia de Amadores de Musica, impresso em Lisboa, Minerva do Comercio, 1917, que contém o Programa.

40 Entre outra documentação alusiva à digressão, conserva-se no Fundo um pequeno bloco de apontamentos de António Fragoso, com o título Despesas e receita da tournée artística de António F. Cabral e A. Lima Fragoso, agosto e setembro de 1917. 


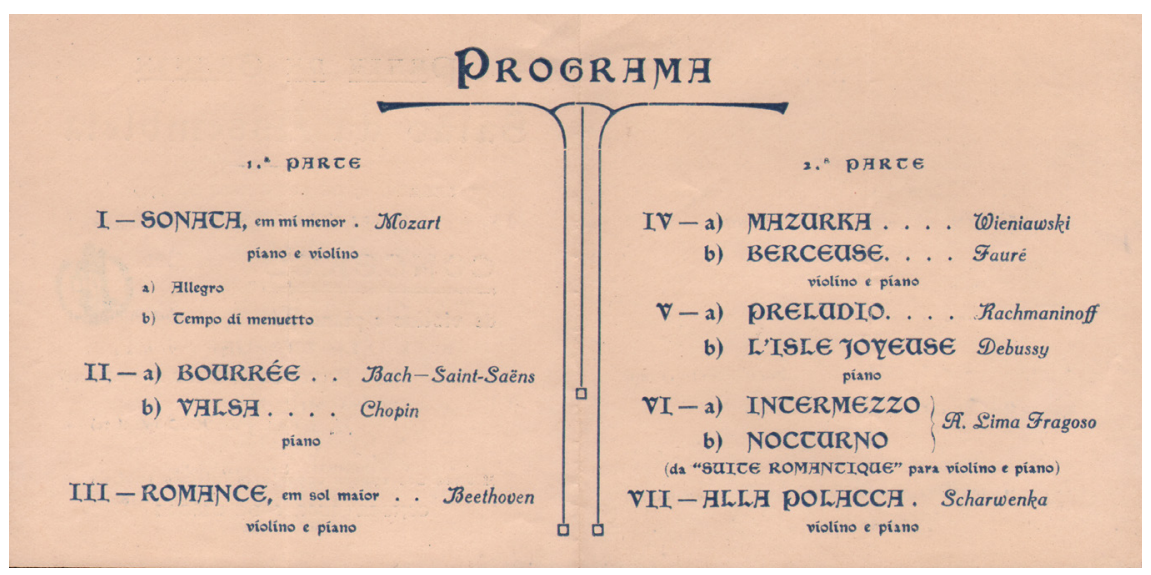

Fig. 8: Programa de concerto por Fernando Cabral (violino) e António Fragoso (piano), Granja, verão de 1917.

O primeiro período do ano letivo de 1917-1918 foi perturbado pela instabilidade política, - o golpe de Estado chefiado por Sidónio Pais, a 8 de dezembro de 1917, e a queda do Governo de Afonso Costa. António Fragoso já em Lisboa, no regresso das férias de Natal passadas como habitualmente na calma e bucólica aldeia da Pocariça, dá conta da sua atenção a esses acontecimentos políticos, a par da animada vida artístico cultural lisboeta, de que destacou as atuações dos Balletts Russes (no Teatro de São Carlos e no Coliseu dos Recreios, em dezembro de 1917), e os concertos de orquestras sinfónicas e de música de câmara. Na mesma carta exprime a sua admiração pela cidade de Paris, «o sonho dourado de todos os artistas.... ${ }^{41}$.

Em julho de 1918, António Fragoso concluiu o terceiro ano do Curso Superior de Piano com a classificação máxima, regressando à Pocariça.

Neste ano de 1918 compôs o Hino da catequese, para a diocese do Porto, e um Cântico para depois da catequese, as únicas duas peças

41 Cf. António Fragoso, minuta de carta, [s. d.], a uma "boa amiga", provavelmente dirigida a Francine Benoît, no início de 1918, que se conserva no Fundo. 
de cariz religioso do seu reportório, possivelmente produzidas por encomenda. É também deste ano o Nocturno para orquestra, com parte de harpa ${ }^{42}$.

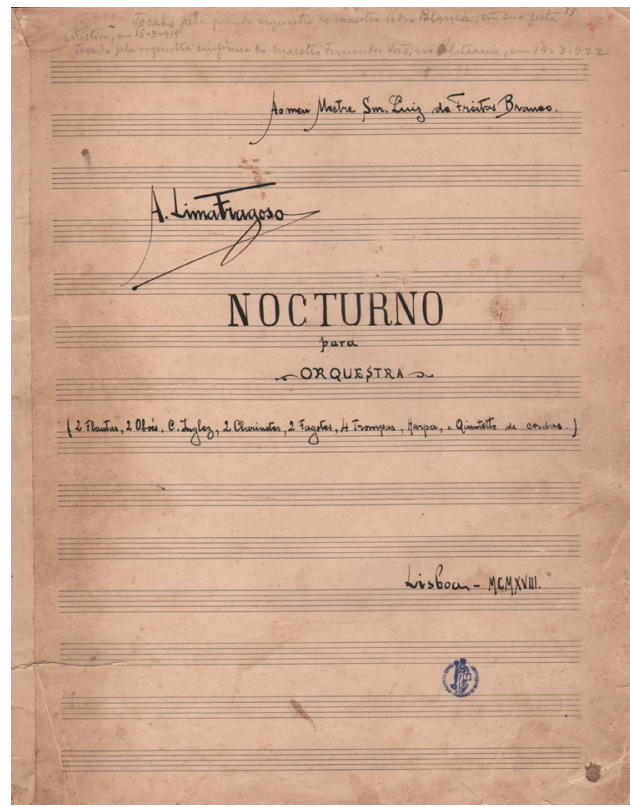

Fig. 9: Página de rosto do Nocturno para orquestra, por António Fragoso, Lisboa, 1918.

Durante o mês de Agosto, repetiu com Fernando Cabral os concertos em estâncias termais, e estudou piano, especialmente Liszt, com o intuito de ir a concurso, pretendendo provavelmente obter o estatuto de pensionista do estado no estrangeiro.

Conforme comunicação de Marcos Garin, as Três peças do século XVIII passaram a integrar o programa de estudos do curso de piano do Conservatório Nacional ${ }^{43}$.

42 A estreia absoluta desta peça aconteceu postumamente, em março de 1919, em Lisboa, no Teatro S. Luís, sob a direção do Maestro Pedro Blanch (cf. VASCONCELOS (1968).

43 Cf. António Fragoso, carta, 13 agosto 1918, Pocariça, ao Professor Marcos Garin, agradecendo-lhe ter incluído as suas Três peças do século VIII no programa do Curso de Piano de Conservatório. 
Ainda durante as férias de Verão, iniciou uma colaboração com o jornal Correio de Cantanhede, onde publicou vários ensaios epistolares ${ }^{44}$, sendo o último, publicado a 3 de outubro, sobre a Música Portuguesa, em resposta a um artigo do maestro e compositor Rui Coelho a propósito da reforma do ensino musical no Conservatório Nacional.

António Fragoso morreu no termo do verão de 1918, a 13 de outubro, vítima da pandemia de gripe pneumónica que devastou o mundo no final da Grande Guerra. No espaço de uma semana, Viriato de Sá Fragoso e Maria Isabel Lima Fragoso, perderam quatro dos seus cinco filhos - António, Maria do Céu (n.1899), Carlos (n.1900) e Maria Isabel (n.1903). Na casa da família, na Pocariça morreram ainda, no mesmo período, três parentes: a tia Corina Guerreiro de Oliveira Lima, Joana da Conceição Soares (n.1891) e Elisa Augusta Soares de Lima (n. 1905).

A morte de António Fragoso teve um grande e duradouro impacto na imprensa, quer pela profunda tragédia que o atingiu e à sua família, quer, igualmente, pela comoção causada pelo desaparecimento de um talento musical único, intérprete exímio e compositor, em pleno desabrochar. Nas notícias publicadas sobressai o sentimento de se estar perante uma perda de valor inestimável para a música e a cultura nacionais ${ }^{45}$.

Quer pela dedicação e persistência da família, quer pelo interesse que sempre foi capaz de suscitar, a produção musical de António Fragoso obteve assinalável impacto, como comprova a inclusão de obras do compositor nos programas de estudos de Piano do Conservatório Nacional. Postumamente surgiram edições de grande parte da sua obra, destacando-se a publicação, em 1923, pela editora musical Valentim de Carvalho, de uma compilação de Composições para piano, em dois volumes, com prefácio de Adriano Merêa, consideradas por

44 Com base em nota no final do artigo publicado a 3 de outubro de 1918, presumese que o autor pretendia compilar estes textos num volume que intitularia Cartas a Maria, cuja edição se encontra em preparação.

45 Cf. por exemplo RIBEIRO (1918 nov. 15) p. 5. 
alguns das mais interessantes páginas da música portuguesa para piano, da época ${ }^{46}$.

No cinquentenário da morte do compositor, em 1968, na Pocariça, frente à casa da família, foi descerrado o busto de António Fragoso. A Fundação Calouste Gulbenkian editou, na série $C$ da coleção Portugaliae Musica, o Nocturno, para orquestra, por António Fragoso, com revisão de J. Croner de Vasconcelos.

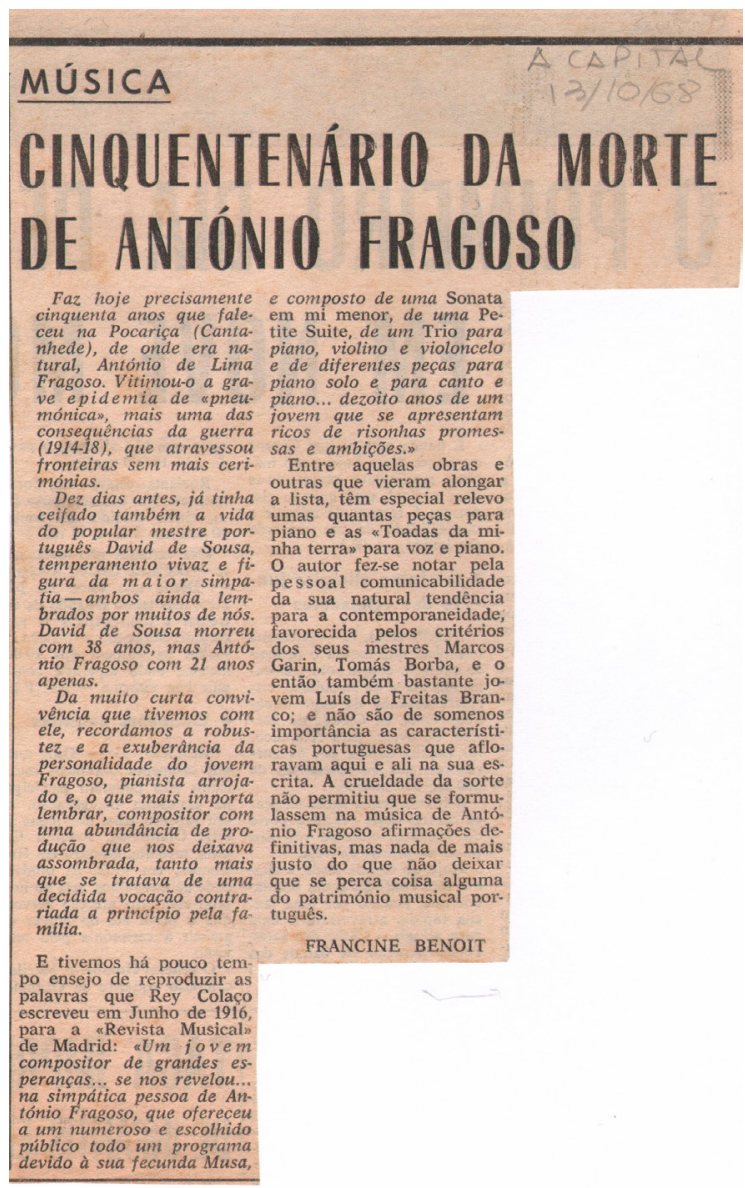

Fig. 10: Recorte do jornal A Capital com artigo de Francine Benoît, «No cinquentenário da morte de António Fragoso».

46 Vd., por exemplo, HINSON \& ROBERTS (2014) p. 394. 
Em 1971, a Editora Musical Valentim de Carvalho procurou fazer uma edição da obra completa de António Fragoso, a partir dos manuscritos originais e cópias avulsas. Esta edição, coordenada por Maria Luísa Garin de Meneses, com o apoio de Maria Fernanda de Sá Fragoso, foi patrocinada pelo Instituto de Alta Cultura ${ }^{47}$.

A música de António Fragoso foi também objeto de diversas edições de registos sonoros, desde a década de 1920, em disco vinil gravado em Londres, até à atualidade, em suportes multimídia.

Desde 2009, a Fundação António Fragoso vem realizando um importante trabalho de divulgação da obra fragosiana promovendo o seu estudo e publicação, orquestração de obras musicais e edição dos textos literários inéditos de António Fragoso, o registo sonoro de interpretações das suas peças, e concertos, entre outras atividades na área artístico musical.

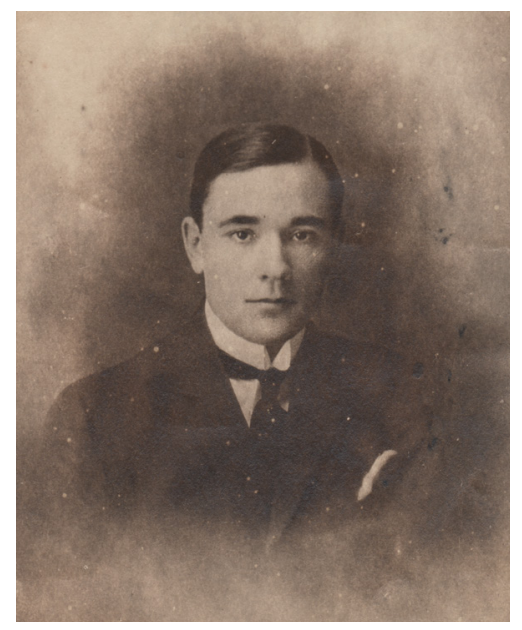

Fig. 11: Retrato de António Fragoso (1918).

47 A publicação, em três volumes, inclui: 1) Sonata em Mi Menor para piano, com revisão da Profa Florinda Santos; 2) Canções do sol poente e Poèmes saturniens, com revisão do Prof. Fernando Lopes-Graça; 3) Suite romantique, com revisão do Dr. Alvaro Cassuto; Trio em Dó sustenido menor, para violino, violoncelo e piano: opus 2, com revisão do Prof. Filipe Pires; Allegro da Sonata (inacabada), em Ré maior, para violino e piano: opus 3, revista pelo Prof. Artur Santos com a colaboração da Prof. Lídia de Carvalho. 
Com o ingresso do Fundo António de Lima Fragoso no seu acervo, a Biblioteca Geral da Universidade de Coimbra, já detentora de um património musical histórico de grande qualidade, variedade e extensão, dos séculos XVI a XVIII, pretende salvaguardar mais um importante espólio musical do século $X X^{48}$ e promover a sua divulgação, proporcionando aos investigadores, aos músicos e ao público especializado o acesso a um valioso e reconhecido património artístico-cultural, a nível nacional e internacional. Com o trabalho de descrição, preservação e disponibilização pública do Fundo António de Lima Fragoso, a BGUC procurou contribuir para assegurar e aprofundar a memória identitária pessoal do músico e local e o património musical português.

3.

\section{FUNDO ANTÓNIO DE LIMA FRAGOSO}

Código de Referência: PT/BGUC/ALF

Título atribuído: Fundo António de Lima Fragoso

48 No fundo musical e musicológico da BGUC, dos séculos XIX e XX, para além de espécies avulsas e pequenas coleções de manuscritos e impressos musicais de proveniências diversas, destacam-se quatro importantes acervos: o Fundo musical Francisco Lopes Lima de Macedo Júnior (c.1859-1939), organista da capela da Universidade de Coimbra, cargo que ocupou pela morte do seu pai, o músico Francisco Lopes Lima de Macedo. Este Fundo, doado à BGUC em 1942 pelos herdeiros, encontra-se parcialmente inventariado e catalogado; o Espólio musical Manuel Faria, constituído pelos manuscritos das partituras da maior parte das obras do cónego Manuel Faria (1916-1983), doado à BGUC por seu irmão Dr. Francisco Faria, em 1983, que se encontra integralmente referenciado, ao nível da peça, no catálogo coletivo das bibliotecas da Universidade de Coimbra; o Fundo musicológico e musical Tenente Manuel Joaquim (1894-1986), adquirido pela BGUC em 1994, constituído por um vasto acervo bibliográfico, musicológico e museológico e pelo arquivo pessoal do musicólogo. Este Fundo, parcialmente inventariado, aguarda tratamento; o Fundo musical e musicológico Maria Augusta Barbosa (1912-2012), que compreende a biblioteca especializada e o arquivo pessoal da musicóloga, fundadora dos estudos superiores universitários musicológicos em Portugal, doado à BGUC pela própria, em 2002. Deste acervo a biblioteca dispõe do inventário da Biblioteca e de uma descrição sumária da composição do arquivo. 
Datas de produção: 1909-2014

Nível de descrição: Fundo

Dimensão e suporte: 8 cx. (ca. 485 docs.) ; 1,20 m lineares

Nome do(s) produtor(es): António de Lima Fragoso; Família Fragoso Martins Soares; Associação António Fragoso

\section{Fonte imediata de aquisição ou transferência:}

O Fundo António de Lima Fragoso foi incorporado na BGUC segundo o termo de doação assinado em cerimónia protocolar na Biblioteca Joanina a 21 de maio de 2014. A documentação deu entrada na Biblioteca Geral da Universidade a 14 de julho do mesmo ano, tendo sido entregue pelo Dr. Eduardo Fragoso Martins Soares, presidente da Associação António Fragoso, na casa de família e sede da Associação António Fragoso, na Pocariça, aos bibliotecários António Eugénio Maia do Amaral, diretor adjunto da BGUC, e Isabel João Ramires.

\section{História custodial e arquivística:}

Após a morte de António Fragoso, o seu espólio musical foi reunido e conservado por seu pai, Dr. Viriato de Sá Fragoso, numa compilação de impressos musicais e partituras manuscritas, originais ou cópias, encadernados juntos num volume com capas de cartão marmoreado e lombada em pele, com autor e título gravados a ferros dourados na lombada. O conteúdo, com dupla numeração - das folhas, a lápis color vermelho, do punho do compilador, e dos documentos, a lápis de carvão, de mão não identificada - originalmente composto por 45 itens ( $257 \mathrm{f}$.), apresentava-se desmembrado e com saltos na numeração, evidenciando a falta de, pelo menos, 10 itens: docs. 17 a 22 (f.103 a 135); doc. 24 (f.141-164); doc. 27 (f.173-182); doc. 30 (f.188-189); 
(f.210-219); doc. 38 (f.222-227) ${ }^{49}$. Aparentemente, os manuscritos foram ordenados segundo o critério cronológico. Para além deste volume, ou «Livro dos originais», a família procurou coligir todos os manuscritos originais, cópias manuscritas e primeiras edições da obra musical de António Fragoso, reunindo mais 37 manuscritos musicais e alguns impressos, avulsos, «anexos ao Livro dos originais». A família conservou também os manuscritos literários, correspondência, materiais efémeros e recortes de impressos e outra documentação, produzidos ou reunidos por António Fragoso ou relativos à sua vida artística. Depois da morte de Viriato Fragoso, em 1945, Maria Fernanda Fragoso Martins Soares (1916-2000), única irmã sobrevivente de António Fragoso, deu continuidade à coleção recolhendo documentação variada relacionadas com a divulgação da obra do compositor e da promoção da sua memória e a sua receção pública, produzida essencialmente por ocasião dos aniversários do nascimento ou da morte do músico ou decorrentes da organização das efemérides. A partir do ano 2009 até a data da doação, a Associação António Fragoso, presidida por Eduardo Fragoso Martins Soares, foi acumulando diversos materiais produzidos no âmbito da sua atividade de divulgação da obra do compositor. Com exceção dos materiais mais recentes, dos registos sonoros e multimídia, e das duas monografias, os documentos encontravam-se dentro de envelopes numerados previamente à transferência para a BGUC.

Desde a entrada na Biblioteca Geral da Universidade de Coimbra, o tratamento técnico e a divulgação do Fundo António de Lima Fragoso foram considerados prioritários. O projeto de tratamento do Fundo,

49 Não se conseguiram identificar os itens em falta. Margarida Prates, na sua dissertação O espólio do compositor António Fragoso (1897-1918): análise do fundo musical e transcrição de sete manuscritos inéditos para piano, apresentada à Faculdade de Letras da Universidade de Coimbra, em 2014, p. 148, faz corresponder às ff.188$189 v$. do volume de Viriato Fragoso, a obra Canção e Dansa portuguesas, para piano, manuscrito a tinta, com assinatura de Jorge da Cruz Jorge, firmada na Pocariça a 10 de Outubro de 1916, constituída pelas peças, Canção, devagar e expressivo; e Dansa [sic], muito alegre. Estes manuscritos não se encontraram no espólio recebido. 
tendo como objetivos a sua organização, descrição e disponibilização pública e o acondicionamento nas condições mais adequadas à sua preservação, teve início em novembro de 2015, encontrando-se em fase de conclusão no final de 2016.

$\mathrm{Na}$ fase inicial do projeto, procedeu-se à identificação e inventariação da totalidade das espécies, respeitando a sequência original, atribuída pelo detentor, conferindo-se uma numeração complementada pela letra "a" a cerca de 60 documentos originalmente sem numeração. Corrigiram-se alguns lapsos e incorreções relativamente à descrição constante do Inventário da Associação António Fragoso que acompanhava o Fundo, nomeadamente quanto à falta das $\mathrm{f}$. 188-189 do volume compilado por Viriato de Sá Fragoso e ao número de fotografias, entre outros.

\section{Âmbito e conteúdo:}

O Fundo é fundamentalmente constituído pelo espólio musical compreendendo as partituras e, ou, partes cavas manuscritas originais e transcrições autógrafas ou de terceiros, das obras de António Fragoso, em parte inéditas, e pelas primeiras edições das partituras publicadas em vida do autor, incluindo exemplares duplicados, alguns com dedicatórias autógrafas; do Fundo fazem também parte as edições póstumas de obras de António Fragoso. No conjunto de Música incluem-se impressões ou fotocópias de três arranjos e/ou orquestrações póstumos, inéditos. Do ponto de vista da categoria musical, o espólio inclui composições para coro a capella, coro com acompanhamento, canto e piano, música para orquestra, música de câmara para orquestra (pequenos grupos de instrumentos), música para instrumento solo (piano, violino e violoncelo) e música religiosa, predominando largamente as peças para piano. De grande parte das peças, essencialmente produzidas em contexto escolar, estão disponíveis as diferentes variantes do processo genético documental, desde apontamentos musicais, estudos e rascunhos a lápis, origi- 
nais e cópias autógrafas e cópias muito cuidadas, provavelmente de outras mãos.

O Fundo compreende o espólio literário de António Fragoso, incluindo manuscritos literários e académicos, nas suas variantes documentais genéticas, e correspondência; cadernos de apontamentos; materiais efémeros, como programas de concertos, etc.; e recortes de jornais, documentação alusiva à vida académica e artística, ou decorrente de atividades relacionadas com a produzida e/ou produzida e reunida por António Fragoso e pela família.

Nesta série documental ressalta a correspondência - mais de uma centena e meia de originais de cartas e bilhetes-postais de António Fragoso aos pais, aos irmãos, aos tios, aos professores e aos amigos, ou recebidos, destacando-se as cartas dirigidas ao pai e aos irmãos António e Maria do Céu. O núcleo epistolar é muito revelador do importante papel formativo das cartas no processo educativo dos jovens na época. Também relevante, um conjunto de trabalhos académicos e ensaios epistolares, escritos principalmente no verão de 1918, com os títulos: "Um grande artista", "O carnaval de Schumann", "O tesouro da Sé", "O novo violonista" e "Música portuguesa", entre outros, em que António Fragoso, dirigindo-se a "uma amiga", destinatária provavelmente fictícia, disserta sobre variados assuntos artístico-musicais. Acompanham esta documentação quatro retratos de António Fragoso (incluindo reprodução de cópia de retrato a sanguínea) e uma fotografia de grupo (13 out. 1968).

Para além do espólio musical e literário do compositor, produzido ou reunido essencialmente entre 1909 e 1918, o Fundo contém uma extensa coleção de caráter memorial - recortes de imprensa, transcrições manuscritas de artigos de jornais e numerosos materiais efémeros, como programas de concertos, convites e correspondência alusiva às edições e transmissão de música de António Fragoso muito completa e representativa da divulgação da obra de António 
Fragoso e da sua receção desde a morte do compositor à atualidade, produzida entre 1918 e 2013, com particular incidência épocas de efemérides. O conjunto inclui o original autógrafo de um poema de António Cândido de Oliveira dedicado a António Fragoso.

O Fundo contem, em anexo, duas monografias, um disco vinil e 10 registos multimídia.

\section{Sistema de organização:}

O Fundo encontra-se organizado nas seguintes séries:

Música (1913-1971)

1.1. Coleção de impressos e manuscritos musicais de António Fragoso, compilados por Viriato de Sá Fragoso

1.2. Música manuscrita: partituras manuscritas e cópias autógrafas e de terceiros

1.3. Música impressa: obras de António Fragoso

1.4. Orquestrações e arranjos póstumos (impressões e fotocópias). Manuscritos

2.1. Coleção de manuscritos, cadernos de apontamentos, correspondência, etc., de António Fragoso, retratos, materiais efémeros e recortes de imprensa, relativos à sua vida e atividades, produzidos ou reunidos entre 1908 e 1919

2.2. Memória: coleção de impressos, recortes de imprensa, efémera e correspondência relativos à vida e à obra de António Fragoso e decorrentes de atividades promovidas para a sua divulgação, produzidos ou reunidos entre novembro 1919 e 2008.

Em anexo: materiais audiovisuais.

Em anexo: monografias.

Na primeira subsérie musical manteve-se a ordem atribuída pelo compilador, segundo o tipo de documento (impressos e manuscritos), estando os manuscritos aparentemente ordenados por data de composição. Na segunda subsérie de Música ordenaram-se as peças 
por efetivo instrumental. Todas as outras subséries seguem a ordem cronológica de produção. Os documentos aos quais não foi possível atribuir uma data precisa, encontram-se no final do período de datação estimado. Aqueles a que não foi possível atribuir qualquer data, encontram-se no final da respetiva série.

Idioma: Português e Francês.

\section{Características físicas:}

Suporte material muitas vezes manchado, fragilizado e deteriorado pela acidez do papel e o manuseamento, com vincos de dobragens e pequenos rasgões, eventualmente manchado de humidade com prejuízo da leitura; necessitando de restauro em alguns casos.

Todos os documentos encontram-se individualmente acondicionados em pastas de papel acid-free. Os manuscritos musicais, para além de inseridos em capilhas acid-free, estão protegidos em pastas de cartolina.

\section{Instrumentos de descrição:}

Inventário ao nível do documento.

Catálogo online das bibliotecas da Universidade de Coimbra, disponível em: http://webopac.sib.uc.pt/search S17, descrição ao nível do documento.

Catálogo dos manuscritos e impressos musicais, publicado no ANEXO do Boletim.

\section{Condições de acesso:}

O Fundo António de Lima Fragoso encontra-se totalmente disponível, podendo ser consultado na Sala de Leitura de Reservados da Biblioteca Geral, no horário de abertura dos serviços, mediante marcação prévia. 


\section{Condições de reprodução:}

A reprodução de documentos encontra-se sujeita a algumas restrições tendo em conta o estado de conservação ou o fim a que se destina a reprodução. A reprodução de documentos está sujeita às normas que regulam os direitos de propriedade e a sua utilização para efeitos de publicação está sujeita a autorização da Direção da BGUC.

\section{Cotas atuais:}

UCBG ALF M.M. / M.I. / Ms.

\section{Nota do arquivista:}

O tratamento do fundo - higienização, carimbagem, inventariação, organização, descrição e acondicionamento da documentação - executado por Sandra Nogueira, com orientação técnica e revisão de Isabel João Ramires, decorreu entre novembro de 2015 e junho de 2016. Agradece-se ao Professor Doutor Paulo Estudante, Professor Auxiliar da Faculdade de Letras da Universidade de Coimbra, a valiosa orientação científico-musicológica. Na descrição do Fundo, em particular da série Musical e da catalogação dos manuscritos e impressos musicais, a dissertação de Mestrado apresentada à FLUC por Margarida Prates (2014) O espólio do compositor António Fragoso (1897-1918): análise do fundo musical e transcrição de sete manuscritos inéditos para piano. Coimbra, 2014, e a publicação dirigida por P. F. de Castro (2010). António Fragoso e o seu tempo: livro de actas do Colóquio Internacional. Lisboa: Associação António Fragoso, em especial os contributos de Paulo Ferreira de Castro e Adriana Latino, Joaquim Carmelo Rosa, Eduardo Fragoso Martins Soares e José Campos, consideram-se obras de referência.

\section{Regras e convenções: ISAD(G)}

ISAD(G) : Norma Geral Internacional de Descrição Arquivística : adoptada pelo Comité de 
Normas de Descrição, Estocolmo (Suécia), 19-22 de Setembro de 1999. Conselho Internacional

de Arquivos ; trad. Grupo de Trabalho para a Normalização da Descrição em Arquivo. $2^{\text {a }}$ ed.

Lisboa : Instituto dos Arquivos Nacionais/Torre do Tombo, 2002

\section{Fontes}

UNIVERSIDADE DE COIMBRA. Biblioteca Geral. Fundo António de Lima Fragoso. 1909-2014. PT/BGUC/ALF M.M./M.I/Ms.

\section{Bibliografia}

BORBA, T. e GRAÇA, F. L. (1996). Dicionário de Música (2a edição, $3^{a}$ tiragem). Vol. 1. Porto: Mário Figueirinhas Ed.

CASTRO, P. F. de. (2010). António Fragoso: uma «figura de culto» da música portuguesa. In P. F. de Castro (Ed.), António Fragoso e o seu tempo: livro de actas do Colóquio Internacional (pp. 81-94). Lisboa: Associação António Fragoso.

CASTRO, P. F. de e LATINO, A. (2010). António Fragoso (1897-1918): lista de obras musicais publicadas. In P. F. de Castro (Ed.), António Fragoso e o seu tempo: livro de actas do Colóquio Internacional (pp. 213-216). Lisboa: Associação António Fragoso

CASTRO, P. F. de e LATINO, A. (2010). Cronologia. In P. F. de Castro (Ed.), António Fragoso e o seu tempo: livro de actas do Colóquio Internacional (pp. 11-18). Lisboa: Associação António Fragoso

FERNANDES, C. (2010). Fragoso, António de Lima. In Salwa Castelo Branco (Ed.), Enciclopédia da Música em Portugal no Século XX (Vol. II, pp. 517-518). Lisboa: Círculo de Leitores; Temas e Debates.

A FESTA (1914 jun. 8) dos alunos do professor de Piano sr. Marcos Garin no «Salão da Ilustração Portugueza». Ilustração Portuguesa. 2. ${ }^{a}$ Série (433) p. 734.

FRAGOSO, V. S. (1997). A Freguesia da Pocariça do Concel ho de Cantanhede: apontamentos

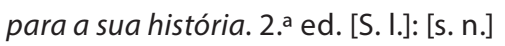

GRAÇA. F. L. (1971). Advertência. In FRAGOSO, A., Canções do sol poente; Poèmes saturniens (p. [3]. Lisboa: Instituto de Alta Cultura.

HINSON, M. e ROBERTS, W. (2014). Guide to the pianist's repertoire (4th ed.) (p. 314). Bloomington \& Indianápolis: Indiana University Press. 
JORGE, L. (1968), António Fragoso: um génio feito saudade. Rio de Janeiro: [s.n.]. Edição patrocinada pela Caixa Beneficente dos Filhos do Concelho de Cantanhede.

MERÊA, P. (1923). António Fragoso. In FRAGOSO, A., Composições para piano (pp. 3-4). Lisboa: Valentim de Carvalho.

MERÊA, P. (1943). Crónicas musicais (pp. 223-226). Barcelos: Oficinas Gráficas da Companhia Editora do Minho.

PRATES, M. (2014). O espólio do compositor António Fragoso (1897-1918): análise do fundo musical e transcrição de sete manuscritos inéditos para piano (Dissertação de Mestrado, Faculdade de Letras da Universidade de Coimbra). Disponível em: http://hdl.handle.net/10316/27564.

RIBEIRO, M. S. (1918 nov. 15). Músicos: António de Lima Fragoso. A Música. A.1 (2).

ROSA, J. C. (2010). O percurso académico-musical de António Fragoso. In P. F. de Castro (Ed.), António Fragoso e o seu tempo: livro de actas do Colóquio Internacional (pp.113-127). Lisboa: Associação António Fragoso.

SOARES, A. (1958 ago. 1). Regentes e reportório da Tuna: algumas notas para a história da Academia de Coimbra. Rua Larga. (16) p. 492.

SOARES, E. F. M. e CAMPOS, J. (2010). António de Lima Fragoso: recordações de família. In P. F. de Castro, António Fragoso e o seu tempo: livro de actas do Colóquio Internacional (pp. 65-80). Lisboa: Associação António Fragoso.

VASCONCELOS, J. C. (1968). Prefácio. In FRAGOSO, A., Nocturno (pp. [5-6]). Lisboa: Fundação Calouste Gulbenkian. 